\title{
Uzman Hekimlerin İstatistiki Yeterlilikleri Hakkında Görüşleri*
}

\section{Opinions of Specialist Physician About Statistics Sufficiency}

Betül Alatlıㄴ (ORCID ID: 0000-0003-2424-5937)

Tufan Alatli ${ }^{1}$ (ORCID ID: 0000-0002-7858-8081)

${ }^{1}$ Dr. Öğretim Üyesi, Gaziosmanpaşa Üniversitesi

Sorumlu Yazar: Betül Alatlı

Gaziosmanpaşa Üniversitesi e-posta: betul.alatli@gop.edu.tr

*Bu çalışma 21-22 Haziran 2018 III. Uluslararası Mesleki ve Teknik Bilimler Kongresinde sözlü bildiri olarak sunulmuştur.

Anahtar Sözcükler:

Tıp eğitimi, Uzman hekim,

Bilimsel çalışma,

İstatistik okuryazarlığı

Keywords:

Medicine education,

Physician,

Scientific Studies,

Statistical literacy

Gönderilme Tarihi

Submitted:06.05.2019

Kabul Tarihi

Accepted: 24.10.2019

ÖZET:

Amaç: $\mathrm{Bu}$ araştırma ile Tıp Fakültesi mezunu farklı uzmanlık alanlarından uzman hekimlerin bilimsel çalışmalar bağlamında istatistiki yeterliliklerine ilişkin görüşlerinin belirlenmesi amaçlanmaktadır.

Gereç ve Yöntem: Araştırma nitel verilerle var olan bir durumun var olduğu şekliyle ortaya konulması amaçlandığından tarama modelinde nitel bir araştırmadır. Araştırma verileri Türkiye'de görev yapan 27 farklı uzmanlık alanından, 53 farklı üniversite ve eğitim araştırma hastanesinde uzmanlık eğitimi almış, farklı kıdem yıllarına sahip (1 ay 33 yıl) 117 uzman hekimin görüşleri üzerinden elde edilmiştir.

Bulgular: Çalışmaya katılan uzman hekimlerin \%91'i hem tez çalışmaları hem de diğer bilimsel çalışmalar bakımından istatistik noktasında yardıma ihtiyaç duymaktadır. Uzmanlık tezi çalışması için gerekli istatistikî işlemleri kendisi yapan uzman hekim oranı sadece \%14,5 olarak tespit edilmiştir. $\mathrm{Bu}$ nedenle bilimsel çalışmalarında birçok şekilde ve yoldan yardım aldıklarını belirtmişlerdir. $\mathrm{Bu}$ türlü yardımları en çok sırasıyla İstatistik uzmanından, Biyoistatistik bölümü öğretim üyelerinden ve kendi bölüm öğretim üyelerinden almaktadırlar. Lisans eğitiminde aldıkları istatistik içerikli derslerin (biyoistatistik vb.) bilimsel çalışmalar noktasında yetersiz kaldığını (\%87) belirtmişlerdir. Uzmanlık eğitimleri boyunca aldıkları istatistik eğitiminin yetersiz olduğunu $(\% 84,6)$ belirtmişlerdir. Uzman hekimler uzmanlık eğitiminde istatistik dersinin yer alması gerektiği (\%86) görüşündedirler.

Sonuç: Uzmanlık eğitimi sürecinde uzman hekimlerin hem tez çalışmaları hem de diğer bilimsel çalışmalar bakımından istatistiki işlemler noktasında yetersiz kaldığı görülmektedir.

Künye: Alatlı B, Alatlı T. Uzman Hekimlerin Istatistiki Yeterlilikleri Hakkında Görüşleri. Tıp Eğitimi Dünyast. 2020;19(57):120-138 
Araştırmaya katılan uzman hekimler lisans eğitiminde aldıkları istatistik içerikli derslerin (biyoistatistik vb.) ise bilimsel çalışmalar noktasında yetersiz kaldığını belirtmişlerdir. Hekimlere göre uzmanlık eğitiminde akademik başarıdan daha çok sağlık hizmetlerinin yürütülmesine önem verildiği, uzmanlık eğitiminin genel olarak standart bir süreç olarak yürütülememesi nedeniyle istatistik eğitiminde de bir standart olmadığı, uzmanlık eğitimi sürecinde eğitim alan hekimlerin iş yükünün fazla olduğu, ancak bireysel çabalar doğrultusunda istatistiki yeterliliklere sahip olabildikleri, istatistiki anlamda yaşanılan problemlerin akademisyenlikten soğutan sebeplerden biri olduğu görüşündedirler.

\section{ABSTRACT:}

Background: In this research, it is aimed to determine the opinions of the specialist physicians from different specialties about their statistical sufficiency in the context of scientific studies.

Methods: The study is intended to reveal an existing situation with qualitative data. Therefore this study is a qualitative study and study's model is survey model. Research data obtained through the 117 physicians from 27 different areas of physicians who work 53 different universities and hospitals, different years of seniority (1 month-33 years) in Turkey.

Results: $91 \%$ of the physicians participating need help in terms of statistics for both thesis studies and other scientific studies. Only 14.5\% of the physicians performing the necessary statistical procedures for the thesis study were determined. For this reason, they stated that they received help in many ways in their scientific studies. These kinds of assistance are mostly from the statistician, the department of Biostatistics and lecturers in their department.
Physicians stated that the courses (biostatistics, etc.) were insufficient (87\%) in terms of scientific studies which had received in the undergraduate education. They stated that the statistical training they received during their specialty training were insufficient (84.6\%). Physicians think that statistics course should be included in residency (86\%).

Conclusions: It is observed that the physicians are insufficient in terms of statistical studies in terms of both thesis studies and other scientific studies. The physicians who participated in the study stated that the courses with statistical content (biostatistics etc.) received in the undergraduate education were insufficient in terms of scientific studies. According to the physicians, it is emphasized that the importance of conducting health services is more important than the academic success, that the specialization education is not a standard process; the opinion that problems experienced in the statistical sense are one of the reasons that cooled down from academics.

\section{GíRiş}

Tüm bilim dallarında olduğu gibi tıp eğitiminde de önemli gelişmeler hızla yayılmaktadır. $\mathrm{Bu}$ gelişmelere paralel olarak alanda yetişen insanların da aynı hızla gelişimlerini sürdürmeleri beklenmektedir. Tıp eğitiminin en önemli öğeleri ise hekimlerdir. Tıp alanında hem eğitici hem de eğitim alan hekimler diğer mesleklerden farklı olarak eğitime ilişkin sorumluluklarının yanı sıra sağlık hizmetlerinin yürütülmesinde de önemli bir role sahiptir. Bu nedenle iki önemli görevi aynı anda ve aynı titizlikle yürütmekte zorlanabilmektedirler. Çünkü her iki görev için güncel bilgileri takip etmek hem daha kaliteli eğitim hem de daha kaliteli sağlık hizmeti adına iki kat çaba gerektirmektedir. Özellikle Türkiye 
gibi gelişmekte olan ülkelerde gelişmişlik düzeylerini etkileyen en önemli faktörün eğitim olduğu bilinmektedir. Bu nedenle Türkiye'nin gelişmişlik düzeyini arttırmak adına eğitim ve eğitim alanında yapılan araştırmalara ve sonuçlarına ihtiyaç vardır. Tıp eğitiminin de bu anlamda araştırma konusu olma adına oldukça önemli bir yere sahip olduğu bilinmektedir. Türkiye'de 1997 yılında ilk olarak Ege Üniversitesi’nde "Tıp Eğitimi” birimi açılmıştır. Bununla birlikte Yükseköğretim Kurulu (YÖK) tarafından 1999 yılında Tıp Eğitimi Anabilim Dalı Ankara, Dokuz Eylül ve Ege Üniversitelerinde kurulmuştur. Aynı zamanda "Tıp Eğitimi” ayrı bir doçentlik alanı olarak kabul edilmiştir. Türkiye'de eğitim veren Tıp fakültelerinin birçoğunda halen "Tıp Eğitimi Anabilim Dalı" bulunmamaktadır (1).

Tıp eğitimi sürecinde, kurumlar tarafından öğrencilere iyi ve kaliteli bir eğitim vermek adına farklı eğitim modelleri kullanılabilmektedir. Bunlara örnek olarak Probleme dayalı öğrenme, Göreve dayalı öğrenme, Mezuniyet hedeflerine dayalı ögrrenme ve Kanıta dayalı öğrenme modelleri gösterilebilir. Ancak kullanılan farklı öğrenme modellerine rağmen eğitim kalitesinin aynı düzeyde ve olabildiğince en üst düzeyde olması beklenir. $\mathrm{Bu}$ durum tıp eğitiminde standardizasyon çalışmalarının önemini ortaya koymaktadır (2). Bu noktada Dünya Tıp Eğitimi Federasyonu, çalışmaları (1998) sonucu uluslararası standartlar programını yürütmüş ve tıp eğitiminin standartlarını biçimlendirmiştir. $\mathrm{Bu}$ çalışmaya göre standartlar üç ana başlık altında toplanmıştır bunlar; Mezuniyet öncesi, mezuniyet sonrası ve sürekli tıp eğitimi şeklindedir (3). Bu başliklarda mezuniyet öncesi olarak anılan kısım tıp fakültelerindeki lisans eğitimini, mezuniyet sonrası olarak adlandırılan uzmanlık eğitimini, sürekli tıp eğitimi ise mesleki yaşam boyunca alınan eğitimi içermektedir. Standartlar incelendiğinde süreç, içerik ve sonucuna yönelik olduğu görülmektedir (4). Ancak bu üç öğe bakımından dünya çapında halen bir standart oluşturulamamıştır. 2002 yılında Türkiye'de "hastalık, durum ve semptomların" bir diğer ifadeyle Tıp fakültelerinde kazandırılması hedeflenen beceri ve tutumların yer aldığı "Ulusal Çekirdek Eğitim Programı” oluşturulmuştur (5). Ancak ilgili program incelendiğinde "bilimsel bilgiyi üreten bireyler yetiştirmek" temeline dayanan hedef veya hedeflere rastlanmamıştır. $\mathrm{Bu}$ anlamda programın sınırlı kaldığı söylenebilir (6). Bununla birlikte benzer bir programin mezuniyet sonrası tıp eğitiminde olmaması ise önemli bir eksiklik olarak görülmektedir.

Bilimsel bilgi birikiminde ve teknolojideki hızlı ilerlemeye bağlı olarak ülkemizde birçok uzmanlık alanı ve yan dal bulunmaktadır. $\mathrm{Bu}$ çeşitliliğin ise giderek arttığı görülmektedir. Ülkemizde tıpta uzmanlık eğitiminde ulusal bir standardizasyonun sağlanması için çalışmalar gerçekleştirilmektedir. 1990'lı yılların başlarından itibaren süregelen iyileştirmeleri, uzmanlık alanlarının temsil gücü olarak dernek ve birliklerin oluşturulması, 1994 yılında Türk Tabipler Birliği (TTB) bünyesinde Uzmanlık Dernekleri Koordinasyon Kurulu'nun (UDDK) kurulması ve ilk Tıpta Uzmanlık Eğitimi Sempozyumu'nun gerçekleşmesi izledi. $\mathrm{Bu}$ mesleki dernekler eğitim müfredatlarını güncellemekte ve merkezi sınavların alt yapısı için ciddi bir çaba sarf etmektedir (7).

T1p fakültesi lisans öğrencileri üzerinde yapılan bir çalışmaya göre araştırmaya katılan öğrencilerin \%98,8'i lisans eğitimini tamamladıktan sonra tıpta uzmanlık eğitimine devam etmek istediklerini \%1,2'si ise pratisyen hekim olarak meslek hayatına devam etmek istediklerini belirtmiştir. Yine aynı çalışmada lisans öğrencilerinin \%77,5'i uzmanlık eğitimi 
sonrası akademik kariyer yapmak istediğini belirtmiştir (8). Türkiye' de uzmanlık eğitimi, bu eğitimi vermekle yetkilendirilmiş hastanelerde örgün eğitim programları ile yürütülmektedir. Mezuniyet sonrası tıp eğitimi diğer bir ifade ile uzmanlık eğitiminde farklı alanların (cerrahi, dahili, temel bilimler) ve bu alanların kendi içinde yer alan anabilim dallarının çeşitliliği standardizasyonu zorlaştırmakta hatta mümkün kılmamaktadır. Tüm bu çeşitliliğe rağmen bütün tıp alanlarından beklenen alana katkı sağlayacak bilimsel çalışmalar gerçekleştirmesidir. Tıp eğitiminin mezuniyet öncesi bölümünde bilimsel çalışmalara katkı sağlayacak araştırma yeterlikleri anlamında sınırlı sayıda ders yer almaktadır; bunlar Biyoistatistik ve Halk Sağlığı dersleridir. Tıp fakültelerinin eğitim programlarının incelendiği bir çalışmada 36 farklı tıp fakültesi eğitim programı incelemiştir. Buna göre tıp fakültelerinin ilk üç yıl için ders saati sayılarının 2151 ile 3568 arasında değiştiği, bu Toplam ders saati içerisinde araştırma ve ilgili derslerin ağırlığının \%1,83 ile \%12,37 arasında değiştiği belirtilmektedir. Programlar incelendiğinde araştırma ile ilgili dersler arasında biyoistatistik, bilgisayar, epidemiyoloji ve bunlara göre daha az sayıda kütüphane ve dokümantasyon, tıp bilişimi, kanıta dayalı tıp ve özel çalışma modülleri adı altında derslerin yürütüldüğü görülmektedir. Buna göre tıp fakültelerinde araştırma eğitimi bakımından bir standart olmadiğ 1 söylenebilir (6). Tıp fakültelerinin eğitim programlarının incelendiği bir çalışmada 100 tıp fakültesi programından 74'ünde biyoistatistik dersinin yer aldığını belirtmektedir (9). Bir diğer çalışmada ise 106 tıp fakültesi eğitim programının 84'ünde (\%80) istatistik veya biyoistatistik içerikli derslerin yer aldığı belirlenmiştir (10). Tıp fakültesi eğitim programlarının incelendiği bir diğer çalışmada ise 28 programdan sadece dokuzunun istatistiksel beceriler üzerine bir eğitim içerdiği belirlenmiştir. $\mathrm{Bu}$ sonuçtan yola çıkılarak hekimlerin sayısal yeteneklerine odaklanan kanıta dayalı 32 saatlik bir tıbbi eğitim programı tasarlanmıştır (11).

Mezuniyet öncesi tıp eğitimi programlarında araştırma eğitimi noktasında bir standart olmadığ1 görülmektedir. Bununla birlikte araştırma eğitiminin daha önceden belirlenmiş bir içeriği mevcuttur. Araştırma eğitimi dört bölümden oluşmaktadır. Bunlar ise araştırma yöntem ve tekniklerinde yeterlilik, ölçme, istatistik ve bilgisayar alanlarıdır (12). Araştırma eğitimi incelendiğinde görüldüğü üzere mezuniyet öncesi tıp eğitimi, araştırma alanından yalnızca istatistiki yeterliklere yöneliktir. $\mathrm{Bu}$ nedenle tıp fakültesi mezunu bir hekim araştırma eğitimi noktasında önemli eksikliklere sahip olarak mezun olmaktadır. $\mathrm{Bu}$ durumun mezuniyet sonrası ve sürekli tıp eğitimi almayan hekimler için kalıcı olduğu bilinmektedir. Buna paralel olarak da alana bilimsel anlamda yapılabilecek katkıları da olumsuz şekilde etkilemektedir.

Mezuniyet sonrası tıp eğitimi diğer adıyla uzmanlık eğitiminde ise araştırma eğitimine ilişkin bir standart bulunmamaktadır. Bilimsel araştırma eğitimi tüm uzmanlık alanları için ortak bir konu alanıdır. Buna göre araştırma eğitiminin tüm uzmanlık alanlarına yönelik standart bir eğitim haline getirilmesi mevcut durumun ortadan kaldırılması noktasında anlamlı görülmektedir.

Tüm tıpta uzmanlık alanları için bilimsel araştırma noktasında standart olan bir durum ise standart olan eğitimin sonunda bir tez çalışması yapma zorunluluğudur. Diğer bir ifade ile tıpta uzmanlık tezi uzmanlık eğitiminin tamamlanması ve diploma alınması için gereken koşullardan birini oluşturmaktadır (13). Tez hazırlama süreci, uzmanlık öğrencilerinin 
hipotez oluşturmasını, veri toplayabilmesini, verilerin analizini yapabilmesini, uygun kaynak kullanımı ile sonuçlarını yorumlayabilmesini hedefleyen bir süreçtir. Tez hazırlama uzmanlık öğrencisinin bilimsel araştırma yapabilme yeterliliğine sahip olma durumunu ortaya koymasının yanı sıra alana katkı sağlamayı da amaçlar. Türkiye'de yapılan bir çalışmanın sonuçlarına göre 328 uzman hekime uygulanan bir anket sonucuna göre uzmanlar bilimsel araştırma yöntemlerine yönelik yeterli eğitim almadığını belirtmektedir. Uzman hekimler uzmanlık eğitimi sürecine ilişkin olarak 'Tez çalışması öncesinde araştırma yöntemlerine yönelik yeterli bir eğitim aldım' sorusuna katılmıyorum (ort 2,5) cevabını vermiştir. Buna ek olarak "Araştırma yöntemleri ve istatistik konularında destek bulmakta güçlük çektim" sorusuna ise kısmen katıldığını belirtmiştir (ort 3.27). Araştırma yöntemlerini içeren yeterli bir eğitim müfredatı olmadığı ve bilimsel araştırma hazırlama noktasında sorunlar yaşandığ 1 belirlenmiştir. Tez hazırlama sürecinin eğitimin bir bölümü olduğu da dikkate alınarak, uzmanlık eğitim programına araştırma yöntemlerine yönelik bilgilerin entegre edilmesi gerekliliği vurgulanmıştır (14). Farklı uzmanlık alanlarının öğretim programı incelendiğinde yalnızca Halk Sağlığı alanında uzmanlık eğitimi alan hekimler bilimsel araştırma yöntemleri ve istatistik eğitimi almaktadır. Tıp eğitiminde bilimsel araştırma eğitiminin eksikliğinin bilinen bir gerçek olmasının yanında Doğu Anadolu Bölgesinde hekimler üzerine yapılmış bir çalışma sonucuna göre çalışmaya katılan \%16,7'si tez dışı çalışmaya katıldığını bildirmiştir. Ayrıca aynı hekimlerin $\% 50$ 'si kariyer planı olarak akademisyenlik, \%23'ü özel sektörde çalışmayı hedeflemektedir. $\mathrm{Bu}$ hekimlerin \%56,7'sinin ise mesleki olarak bir akademik yayın organına üyeliği bulunmaktadır, ancak makale okuma ve özetleri gözden geçirmede zaman sıkıntısı yaşamaktadır. Çalışmaya katılan uzman hekimlerin yurtiçi yayın oranı oldukça düşük olarak saptanmış olup hekimlerin çoğunun yurtdışı yayını bulunmamaktadır (15). Uzmanlık eğitimi süresince hekimlerin bilimsel yayın sahibi olmalarının sadece tez yazım aşamasına hazırık ya da hekimlik uygulamalarına katkısı olması dışında, hekim açısından önemli bir özgüven sebebidir (16). Marmara Üniversitesi T1p Fakültesinde yapılmış bir araştırma sonucuna göre 1983-2009 yılları arası bütün yayınların \%64,7'si Tıp Fakültesinden çıktığı bildirilmiştir. Benzer şekilde Türkiye kaynaklı yayınlar içinde \%33'lük bir oranla Tıp Fakülteleri birinci sırada yer almaktadır (17). Diğer alanlara göre daha fazla bilimsel çalışmanın yapıldığı tıp alanında bilimsel araştırma eğitimi noktasında bir standardın bulunmaması, hekimlerin aldıkları eğitimi yetersiz olarak nitelendirmesi ve bu anlamda yeterince destek bulamadıklarını belirtmeleri dikkat çekmektedir.

Uzmanlık tezi hazırlayabilmek ve bilimsel araştırmalar yapabilmek için bilimsel araştırma yöntemleri ile birlikte araştırma eğitiminin ana parçalarından biri olan istatistik eğitiminin de uzmanlık eğitimi programında yer alması önemli görülmektedir. Uzman hekimlerin istatistik veya araştırma alanında kendilerini geliştirmeleri için özel bir çaba göstermeleri gerekmektedir. Bu özel çaba için ise zamana ve alan uzmanlarına ihtiyaçları vardır. Hekimler vakitlerinin çoğunu sağlık hizmeti sağlamak üzere harcamaktadırlar. Tip Fakülteleri ve Eğitim Araştırma Hastanelerini kapsayan bir çalışmada da tıpta uzmanlık eğitimi alan hekimler verdikleri sağlık hizmet yoğunluğunun vermiş olduğu yük altında ezilmekte, gördükleri eğitim ile tatmin olamamakta, eğitimdeki bozukluklar ile başarı ve yeterliliklerinin tam 
olarak kazanılamayacağını belirtmektedirler (15). Bu noktada hekimin uzmanlık alanının ne olduğu önem kazanmaktadır. Birçok uzmanlık alanında hekimin sağlık hizmeti dışında kendini geliştirmek üzere alacağı herhangi bir eğitime vakti kalmamaktadır. Uludağ Üniversitesi asistan ve uzman hekimleri üzerinde yaptığı bir çalışma sonuçlarına göre çalışmaya katılan hekimlerin \%18'i yaşam kalitesini biraz kötü ve kötü olarak değerlendirmiştir. Bu çalışma sonuçlarına göre özellikle araştırma görevlilerinin bedensel, sosyal ve çevresel olarak yaşam kalitesi düşük bulunmuştur (18). Eğer hekimin sağlık hizmeti için harcadığı zaman azaltılabilirse istatistik, araştırma vb konularda kendi çabalarıyla veya müfredat çerçevesinde daha iyi bir eğitim alabilirler.

Tıp eğitiminde, araştırma eğitimi yalnızca istatistik içerikli dersler ile ve mezuniyet öncesi süreçte yer almaktadır. Bununla birlikte istatistik eğitiminin nihai amaçlarından biri ise istatistik okuryazarlığı yüksek bireyler yetiştirmektir (19). Diğer bir ifadeyle istatistik eğitiminin, yalnızca bilgi, formül, sayısal hesaplamalar üzerinden yürütülmesi yerine bireylerin istatistik okuryazarlığına ilişkin tüm becerilere yönelik yürütülmesi önerilmektedir (20). İstatistik okuryazarlı̆̆ 1 tanımlamaları incelendiğinde istatistiğe özgü terim, kelime ve sembolleri kavrama, grafik ve tablolarda yer alan bilgileri yorumlama, karşılaşılan farklı bağlamlarda (haber, yaşam, medya) istatistik verilerini okuma, yorumlama ve görüş geliştirme becerileri olarak tanımlanmaktadır $(21 ; 22 ; 23 ; 24 ; 25 ; 26 ; 27 ; 28 ; 29)$. Buna göre istatistik eğitimi alan hekimlerin de belirtilen bu özelliklere sahip olması beklenmektedir.

İlk olarak 1937'de sadece laboratuvarda değil klinik tıpta da istatistiksel değerlendirmelerin gerekli olduğu belirtilmiştir (30). 1937'den bu yana internet üzerinde geniş çapta bir bilgi ağının kullanıma hazır olması, teknolojik gelişmeler, erken teşhis için yapılan ölçümler gibi kültürel ve sosyal anlamda birçok değişiklik meydana gelmiştir. $\mathrm{Bu}$ türlü gelişmeler istatistiksel anlamda yeterliliklerin daha çok kullanımını gerektirmektedir. Patologların istatistik okuryazarlığının incelendiği bir çalışmada 18 istatistiksel teknik için çoğu patolog hiçbir bilgisi olmadığını veya temel bilgi seviyesinde olduğunu belirtmiştir. İstatistiksel okuryazarlığı ile araştırma yayınlama veya bir istatistik kursu alma durumları arasında pozitif bir ilişki olduğu belirlenmiştir (31). Jinekologların istatistik okuryazarlığının incelendiği bir diğer çalışmada ise hekimlere istatistiksel okuryazarlık eğitimlerini nasıl aldıkları sorulduğunda \%56's1 dergi kulübü adı verilen bir grup doktorun, genellikle haftalık veya aylık bazda, tıp dergilerinden sınırlı sayıda makaleyi tartıştığı, analiz ettiği ve gözden geçirdiği eğitimlerden, \%29'u informal eğitimlerden, \%15'i dersin bir parçası olarak, \%11'i ise herhangi bir eğitim almadığını belirtmiştir (32). Araştırma sonuçları incelendiğinde eğitim sürecinde aldıkları derslerden istatistiki yeterlilikler kazandığını belirten uzman hekim oranı oldukça düşüktür. Bunun yanı sıra Türkiye'de uzman hekimlerin istatistik okuryazarlığı üzerine yapılmış herhangi bir çalışmaya rastlanmamıştır.

Birçok bilim alanında olduğu gibi Tıp alanında da istatistik eğitiminin yeri hekimler tarafindan yapılacak bilimsel araştırmalar ve yapılan araştırmaların anlaşılırlı̆̆ noktasında oldukça önemlidir. Buna göre hekimler için istatistiksel yeterlilikler yalnızca bilimsel çalışmalar yürütebilmek adına değil, tıbbi kararlar alabilmek, bilimsel dergilerde yer alan çalışmaları anlayabilmek adına da gerekli görülmektedir. $\mathrm{Bu}$ durum tıp eğitiminde istatistiğin yerinin incelenmesine ve bu konuda gerekli önerilerin sunulmasına ilişsin 
çalışmaların da önemini arttırmaktadır. Üç bölümden oluşan Tıp eğitiminin sadece mezuniyet öncesi kısmında sınırlı sayıda istatistik dersinin yer alması, bilimsel araştırma ve tez hazırlama gerekliliklerinin bulunduğu mezuniyet sonrası diğer bir ifadeyle Tipta uzmanlık eğitiminde ise istatistiğin bir yerinin olmaması dikkat çekmektedir. $\mathrm{Bu}$ durum hekimlerde istatistik okuryazarlığının gelişimi, Tıp alanında yapılan çalışmaların geçerliliği, güvenilirliği ve anlaşılırlığı adına da önemli eksikliklere neden olabilmektedir. Bununla birlikte belli sayısal veriler üzerinden tıbbi kararlar veren uzman hekimler için istatistik okuryazarlığı oldukça önemli bir yere sahiptir. Buna göre farklı uzmanlık alanlarından uzman hekimlerin istatistiki yeterliliklerine ilişkin görüşlerinin belirlenmesi bu eksikliklerin ortaya konulması açısından önemli görülmektedir. $\mathrm{Bu}$ nedenle bu araştırmada uzman hekimlerin uzmanlık eğitiminde istatistiğe ilişkin görüşlerini belirlemek amacıyla şu sorulara yanıt aranmıştır:

1. Uzman hekimler uzmanlık eğitimi süresince yaptıkları bilimsel çalışmalarda istatistiksel açıdan yardıma ihtiyaç duymakta mıdır? Kimlerden, ne gibi yardımlar almaktadır?

2. Uzman hekimler, uzmanlık tezi çalışmaları için gerekli istatistikî işlemleri kendileri mi yapmaktadır? Kimden ne gibi yardımlar almaktadır? $\mathrm{Bu}$ süreçte ne gibi sorunlarla karşılaşmaktadır?

3. Uzman hekimler lisans eğitiminde aldıkları istatistik içerikli derslerin bilimsel çalışmalar için yeterli olduğunu düşünüyor mu?

4. Uzman hekimlere göre tıpta uzmanlık eğitiminde istatistik dersi yer almalı $\mathrm{m}$ ? $\mathrm{Bu}$ konuda görüşleri nelerdir?"

5. Uzman hekimlerin tıpta uzmanlık eğitiminde istatistiğin yerine ilişkin görüşleri nelerdir?"

\section{GEREÇ VE YÖNTEM}

\section{Araştırma Modeli}

$\mathrm{Bu}$ araştırma nitel verilerle var olan bir durumun var olduğu şekliyle ortaya konulması amaçlandığından tarama modelinde olgu bilim (fenomenoloji) desenine dayalı nitel bir araştırmadır (12). Olgu bilim araştırmaları, farkında olduğumuz fakat ayrıntılı veya derinlemesine bilgi sahibi olmadığımız olguları araştırmayı amaçlar. Bu türlü araştırmalarda veri kaynakları olguyu yaşayan ve buna ilişkin veri sağlayabilecek bireylerden oluşmaktadır (33). Araştırmacı, katılımcılar tarafindan tanımlanan bir olgu hakkında, insan deneyimlerini açığa çıkarmak için uygulanan bir sorgulama stratejisi yürütür (34). $\mathrm{Bu}$ nedenle bu araştırmada uzman hekimlerin istatistiki yeterliliklerine ilişkin olguların, uzman hekimlerin görüşleri doğrultusunda ayrıntılı ve derinlemesine incelenmesi amaçlandığından araştırma olgu bilim araştırması olarak desenlenmiş̧ir

\section{Evren ve Örneklem}

$\mathrm{Bu}$ araştırmanın evrenini uzmanlık eğitimini tamamlamış uzman hekimler oluşturmaktadır. Araştırmada amaçlı örnekleme yöntemlerinden kartopu örnekleme kullanılmıştır. Amaçlı örnekleme, zengin bilgi içeriğine sahip olduğu düşünülen durumların derinlemesine çalışılmasına imkan tanımaktadır. Amaçlı örnekleme yöntemlerinden kartopu örnekleme ise zengin bilgi kaynağı olduğu bilinen bireylerden veriler sağlanarak bu bireylerin önerilerinden yola çıkılarak ulaşılan birey sayısının arttırılmasına dayanmaktadır (35). Buna göre bu araştırmada uzman hekimlerin istatistiki yeterliliklerine ilişkin görüşlerini belirlemek amaçlandığından araştırmanın örneklemini Türkiye'de görev yapan 27 farklı 
uzmanlık alanından, 53 farklı üniversite ve eğitim araștırma hastanesinde uzmanlık eğitimi almış, farklı kıdem yıllarına sahip 117 uzman hekim oluşturmaktadır. Araştırmanın örnekleminde yer alan uzman hekimlerin uzmanlık alanlarına göre dağılımı Tablo 1'de yer almaktadır.

Uzmanlık alanlarına göre dağılımları incelendiğinde çalışma grubunda en çok Dahiliye (13) ve Acil Tip (13) alanlarından

Tablo 1. Uzman Hekimlerin Uzmanlık Alanlarına Göre Dağılımı

\begin{tabular}{llll}
\hline Bölüm & F & Bölüm & F \\
\hline Dahiliye & 13 & Aile Hekimliği & 3 \\
Acil & 13 & Radyoloji & 3 \\
Genel Cerrahi & 8 & Ortopedi & 3 \\
KHD & 7 & FTR & 3 \\
Üroloji & 6 & Göz & 2 \\
Pediatri & 6 & Kardiyoloji & 1 \\
Anestezi & 6 & Enfeksiyon & 1 \\
KBB & 5 & Dermatoloji & 1 \\
Beyin Cerrahi & 5 & Dahiliye-Yoğun Bakım & 1 \\
Nöroloji & 5 & KVC & 1 \\
Göğüs Hastalıkları & 5 & Göğüs Cerrahisi & 1 \\
T1bbi Biyokimya & 4 & Anatomi & 1 \\
Halk Sağlığı & 3 & Plastik Cerrahi & 1 \\
Psikiatri & 3 & Cocuk Cerrahi & 1 \\
\hline
\end{tabular}

uzman hekimlerin yer aldığı görülmektedir. belirlenmiştir. Uzman hekimlerin kıdem yılına Uzman hekimlerin kıdem y1lı incelendiğinde göre dağılımları ise Tablo 2'de yer almaktadır. ortalama kıdem yılı yaklaşı 5 yıl olarak

Tablo 2. Uzman Hekimlerin Kıdem Yılına Göre Dağılımı

\begin{tabular}{lll}
\hline Kıdem Yllı & f & $\mathbf{\%}$ \\
\hline 1 ve altı & 24 & 20,5 \\
2 & 19 & 16,2 \\
3 & 11 & 9,4 \\
4 & 12 & 10,3 \\
5 & 13 & 11,1 \\
6 & 5 & 4,3 \\
7 & 8 & 6,8 \\
8 & 6 & 5,1 \\
9 & 3 & 2,6 \\
10 ve üzeri & 16 & 13,7 \\
Toplam & 117 & 100 \\
\hline
\end{tabular}


Tablo 2 incelendiğinde çalışma grubunda yer alan uzman hekimlerin kıdem y1lı bakımından en çok \%20,5 ile 1 yıl ve altı kıdem yılına sahip oldukları belirlenmiştir. Bununla birlikte kıdem yılı bakımından en düşük 1 aylık, en yüksek 33 yıllık kıdeme sahip uzman hekim bulunmaktadır. Farklı kıdem yıllarından uzman hekimlerin olması araştırma sorularına verilen yanıtlar bakımından önemli görünmektedir. Özellikle kıdem yılı 5 yıl ve altı uzman hekimlerin çalışma grubunun \%67,5'unu oluşturması uzmanlık eğitimlerinin üzerinden uzun yıllar geçmemesi görüşme soruları bakımından daha faydalı görülmektedir. Araştırma örnekleminde yer alan uzman hekimlerin uzmanlık eğitimini aldıkları üniversitelere göre dağılımı ise Tablo 3 'te yer

Tablo 3. Uzman Hekimlerin Çalıştığı Kuruma Göre Dağılımı

\begin{tabular}{llll}
\hline Üniversite & F & Üniversite & F \\
\hline Adnan Menderes Ünv & 1 & Hacettepe Ünv. & 2 \\
Afyon Kocatepe Ünv & 3 & Haseki Hast & 1 \\
Akdeniz Ünv & 5 & Ïnönü Ünv. & 2 \\
Ankara EAH & 2 & İstanbul EAH & 3 \\
Ankara Numune EAH & 2 & Istanbul Göztepe EAH & 1 \\
Ankara Ünv. & 7 & İstanbul Ünv & 3 \\
Bakırköy EAH & 1 & İstanbul Zeynep Kamil & 1 \\
Baltalimanı Hast & 1 & İzmir EAH & 1 \\
Başkent Ünv. & 2 & Kayseri EAH & 2 \\
Bozok Ünv & 1 & Kirıkkale Ünv. & 1 \\
Bursa EAH & 1 & Kocaeli Ünv. & 1 \\
Cerrahpaşa & 2 & Konya EAH & 1 \\
Cumhuriyet Ünv. & 2 & Meram Tip F. & 2 \\
Dişkapı & 2 & Okmeydanı EAH & 1 \\
Dicle Ünv & 2 & Ondokuz Mayı Ünv. & 4 \\
Dokuz Eylül Ünv & 2 & Osmangazi Ünv & 1 \\
Dr. Suat Seren Göğüs Hast & 1 & RTE Ünv. & 1 \\
Düzce Ünv. & 2 & Sami Ulus EAH & 1 \\
Ege Ünv & 3 & Selçuk Ünv. & 1 \\
Erciyes Ünv & 4 & Süleyman Demirel Ünv & 1 \\
FSM EAH & 1 & Sütçü imam Ünv & 1 \\
GATA & 3 & Şişli Etfal & 1 \\
Gazi Ünv & 6 & Tepecik SSK & 1 \\
Gaziantep Ünv. & 4 & Ufuk Ünv. & 1 \\
Gaziosmanpaşa Ünv. & 18 & Uludağ Ünv. & 1 \\
\hline
\end{tabular}

almaktadır. Tablo 3 'te yer alan uzman hekimlerin üniversitelere göre dağılımları incelendiğinde 54 farklı üniversiteden uzmanın araştırma grubunda yer aldığı görülmektedir. $\mathrm{Bu}$ durum araştırmanın alt amaçları düşünüldügünde elde edilen bulguların farklı üniversitelerin uzmanlık eğitimleri üzerinden elde edilmesi noktasında önemli görülmektedir. 


\section{Veri Toplama Aracı}

Nitel veri toplama teknikleri ile ele alınan bu araştırmada, kaynak kişilere yöneltilen, herkes tarafindan aynı şekilde anlaşılacak ve araştırma amaçlarına uygun soru listesi olarak adlandırılan sistemli bir veri toplama tekniği olarak nitelendirilen anket kullanılmıştır (36). Araştırmada araştırmanın amaçları doğrultusunda araştırmacılar tarafından 7 maddeden oluşan anket formu geliştirilmiştir. Anket formunda yer alan sorular Tipta uzmanlık eğitimini tamamlamış 5 hekim, bir ölçme ve değerlendirme uzmanı ve bir Türk Dili ve Edebiyatı uzmanı tarafından incelenmiş ve uzman görüşleri doğrultusunda gerekli düzeltmeler yapılmıştır. Anket öncelikle uzman hekimlerin hangi alanda ve üniversite veya eğitim araştırma hastanesinde uzmanlık eğitimlerini aldıkları ve kaç yıldır uzman hekim olarak çalıştıkları sorularına ek olarak uzmanlık eğitiminde bilimsel çalışmalar ve tez çalışmasında istatistiksel açıdan yardım alıp almadıkları, aldılar ise kimden aldıkları sorgulanmıştır. Bunlara ek olarak lisans ve uzmanlık eğitimlerinde istatistik derslerine ve son olarak da tıpta uzmanlık eğitiminde istatistiğin yerine ilişkin yanıtların alınmasını amaçlayan sorular yer almaktadır.

Araştırma verileri e-posta yoluyla toplanmıştır ve yazılı olarak kaydedilmiştir.

Veriler, Ocak 2018 ile May1s 2018 tarihleri arasında toplanmıştır.

\section{Verilerin Analizi}

Araştırmada elde edilen nitel veriler içerik çözümlemesi tekniği kullanılarak analiz edilmiştir. İçerik analizi yazılı veya sözlü materyallerin sistemli bir şekilde çözümlenip, insanların yazdıkları ve söylediklerinin açık talimatlara göre kodlanarak nicelleştirilmesi süreci olarak tanımlanmaktadır $(37,38)$.

İçerik çözümlemesi, "Sözel veya yazılı verilerin belirli bir problem veya amaç bakımından sınıflandırılması, özetlenmesi, belirli değişken veya kavramların ölçülmesi ve bunlardan belirli bir anlam çıkarılması için taranarak kategorilere ayrılması" olarak tanımlanmaktadır (38).

Nitel verilerin yer aldığı bir çalışmada geçerli bir anlam ve sonuç çıkarma için temalar oluşturulmuş, zıtlık ve karşılaştırmalar yapılmış benzerlerin gruplanmasına dikkat edilmiş, bazı değişkenlere ilişkin frekanslara ve yorumlarına yer verilmiştir $(33,39)$. Analiz sürecinde her bir uzman için kod (U1,U2 ... .vb) verilmiştir. Her bir maddeye ilişkin oluşturulan temalar üzerinden frekans ve yüzdeler hesaplanmıştır.

\section{BULGULAR}

$\mathrm{Bu}$ bölümde araştırma amaçları doğrultusunda katılımcılara yöneltilen görüşme sorularına verilen yanttlar üzerinden elde edilen bulgular ve yorumlara yer verilmiştir. Araştırmanın birinci alt amacı doğrultusunda katılımcılara “Uzmanlık eğitimi süresince yaptığınız bilimsel çalışmalarda (makale, sözlü sunum, poster vb.) istatistiksel açıdan yardıma ihtiyaç duydunuz mu? Eğer bir yardım aldıysanız kimden, ne gibi yardımlar aldınız?" soruları yöneltilmiştir. Elde edilen bulgular ise Tablo 4'te yer almaktadir. Katılımcılar yardım aldıkları kişiler bakımından yanıt verirken birden fazla kişiden yardım aldıklarını belirtmişlerdir. 
Tablo 4: Uzman Hekimlerin Uzmanlık Eğitimi Süresince Yaptıkları Bilimsel Çalışmalarda İstatistiksel Açıdan Yardım Alma Durumlarına İlişkin Dağılım

\begin{tabular}{lcl}
\hline $\begin{array}{l}\text { Uzmanlık eğitimi süresince yaptığınız bilimsel çalışmalarda istatistiksel } \\
\text { ihtiyaç duydunuz mu? }\end{array}$ & \multicolumn{2}{c}{ aç yardıma } \\
\hline & 106 & $\%$ \\
\hline Evet & 11 & 90,60 \\
Hayır & 117 & 100,00 \\
Toplam & \multicolumn{2}{c}{ f } \\
\hline Eğer bir yardım aldıysanız kimden, ne gibi yardımlar aldınız? & 32 & 24,62 \\
\hline İstatistik uzmanı & 30 & 23,08 \\
Biyoistatistik bölümü öğretim üyeleri & 27 & 20,77 \\
Bölüm öğretim üyeleri & 17 & 13,08 \\
Diğer & 11 & 8,46 \\
Halk sağlığı bölümü öğretim üyeleri & 10 & 7,69 \\
Kendim & 3 & 2,31 \\
Danışman & 130 & 100,00 \\
Toplam &
\end{tabular}

Buna göre Tablo 4'te görüldüğü gibi toplam 117 uzmandan 130 yanıt alınmıştır.

Tablo 4'te yer alan bulgular incelendiğinde araştırmaya katılan 117 uzmandan 106'sının uzmanlık eğitimi sürecinde yaptığı bilimsel çalışmalarda istatistiksel açıdan yardıma ihtiyaç duyduğu görülmektedir. Bilimsel çalışmalarında yardıma ihtiyaç duymayan 11 uzman hekimden 10'u bilimsel çalışmalarında istatistiksel işlemleri kendinin yaptığını belirtirken bir uzman hekim bilimsel çalışma yapmadığını belirtmiştir. Bilimsel çalışmalarında istatistiksel yardımın en çok sırasıyla istatistik uzmanı $(n=32)$, biyoistatistik uzmanı $(n=30)$, bölüm öğretim üyeleri ( $n=27)$ ve halk sağlığı bölümü öğretim üyeleri $(n=11)$ tarafindan sağlandığını belirtmiştir. Bununla birlikte danışman $(n=3)$, kendi bölümü veya diğer bölümlerde uzmanlık eğitimi alan hekimler $(n=12)$, web desteği $(n=1)$ ile de istatistiksel işlemlerini gerçekleştirdikleri görülmektedir. Uzman hekimlerden 13'ü ise bilimsel çalışmalarında istatistiksel bakımdan yardımı iki ve daha fazla kaynaktan aldığını söylemektedirler. Uzman hekimlerden 8'i istatistiksel işlemleri ücret karşılığı yaptırdığını vurgulamıştır. 
Tablo 5: Uzman Hekimlerin, Uzmanlık Tez Çalışması için Gerekli İstatistikî İşlemlere İlişkin

Yanıtlarının Dağılımı

\begin{tabular}{lll}
\hline Uzmanlık tezi çalışmanız için gerekli istatistikî işlemleri kendiniz mi yaptınız? & \\
\hline \multicolumn{1}{l}{ Evet } & $\mathrm{f}$ & $\%$ \\
Hayır & 17 & 14,53 \\
Yanıt yok & 99 & 81,20 \\
Toplam & 1 & 0,85 \\
\hline Eğer bir yardım aldıysanız kimden aldınız? & 117 & 100,00 \\
\hline İstatistik Uzmanı & & \\
Biyoistatistik bölümü öğretim üyeleri & 40 & 33,33 \\
Kendim & 22 & 18,33 \\
Danışman & 17 & 14,17 \\
Diğer & 10 & 8,33 \\
Halk sağlığı bölümü öğretim üyeleri & 10 & 8,33 \\
Bölüm öğretim üyeleri & 8 & 6,67 \\
İstatistik şirketine & 8 & 6,67 \\
Toplam & 5 & 4,17 \\
& 120 & 100,00 \\
\hline
\end{tabular}

Araştırmanın ikinci alt amacı doğrultusunda "Uzmanlık tezi çalışmanız için gerekli istatistikî işlemleri kendiniz mi yaptınız? Eğer kendiniz yapmadıysanız kimden ne gibi yardımlar aldınız? Bu süreçte ne gibi sorunlarla karşılaştınız? Görüşleriniz nelerdir?” sorusuna verilen yanıtlara ilişkin bulgular Tablo 5'te yer almaktadır. Katılımcılar yardım aldıkları kişiler bakımından yanıt verirken birden fazla kişiden yardım aldıklarını belirtmişlerdir. Buna göre Tablo 5'te görüldüğü gibi toplam 117 uzmandan 120 yanıt alınmıştır.

Araştırmanın çalışma grubunda bulunan 117 uzman hekimden 99'u (\%81,2) uzmanlık eğitimlerinin sonunda yaptıkları tez çalışmasına ilişkin istatistiki işlemleri kendilerinin yapmadığını belirtmiştir (Tablo 5). Bununla birlikte uzman hekimlerin en çok yardım aldıklarından en az yardım aldıklarına doğru sırasıyla İstatistik uzmanı $(\mathrm{n}=40)$, Biyoistatistik bölümü öğretim üyeleri $(\mathrm{n}=22)$, Danışman $(n=10)$, Halk sağlığ 1 bölümü öğretim üyeleri $(\mathrm{n}=8)$, bölüm öğretim üyeleri $(\mathrm{n}=8)$ ve istatistik şirketine $(n=5)$ olmak üzere çeşitli yollardan yardım aldıkları şeklinde yanıt vermişlerdir. Tablo 5'te yer alan diğer yardım aldıkları kişiler ise diğer uzman veya uzmanlık eğitimine devam eden hekimlerden yardım almışlardır.
Hekimlerden dokuzu aldıkları yardım karşıllı̆ında ücret ödediklerini belirtmektedirler. Tez çalışmasında istatistiki işlemlerini kendinin yaptığını belirten 17 uzmandan ikisi uzmanlık eğitimlerinde istatistik ile ilgili eğitimler aldıkları yanıtını vermiştir. Örneğin bir uzman hekimin yanıtı şu şekildedir; "Asistanlığım süresince sürekli istatistik eğitimi aldım".

Uzman hekimleri tez çalışmaları sürecinde ne gibi sorunlar ile karşılaştıkları da görüşme soruları arasında yer almaktadır. Ancak sadece $30(\% 26)$ uzman yaşadıkları sorunlar ile ilgili açıklama yapmıştır. Buna göre uzmanlardan 10'u istatistik konusunda yardım aldıkları kişilerle ilgili sorunlar yaşadıklarını belirtmektedir. Örneğin bir uzman hekim; “Tez istatistiklerimi istatistik uzmanı yapt1, ücretler pahalı ve ilgi azdı" yanıtını vermiştir. Bir başka uzman hekim ise "başka klinik hocaları yardım etti, başkasına bağımlı olmak sıkıntı oldu" şekilde yanıtlamıştır. Bir diğer uzman hekimin yanıtı ise şu şekildedir; "Tez istatistiklerimi Biyoistatistik hocası ile yaptım, birçok kez ziyaret etmek zorunda kaldım".

Uzman hekimlerden dokuzu ise, tez çalışmaları süresince yaşadıkları sorunlardan bir diğerinin elde edilen bulguları değerlendirme ile ilgili olduğunu belirtmiştir. Örneğin bir uzman "tez 


\begin{tabular}{lll}
\hline & $\mathrm{f}$ & $\%$ \\
\hline Yetersiz & 102 & 87,18 \\
Yeterli & 15 & 12,82 \\
Toplam & 117 & 100,00 \\
\hline
\end{tabular}

istatistiklerimi istatistik uzmanına yaptırdım, tartışma ve sonuç kısmında zorlandım" şeklinde yanıt vermiştir. Bir diğer uzman ise "Danışman hocam ve biyoistatistik hocalarından yardım aldım, sonuçları değerlendirmede zorlandım" şeklinde yanıtlamıştır. Uzman hekimlerden altısına göre tez çalışmalarında yaşadıkları bir diğer sorun ise tez istatistiklerinin yardım alınarak yapılmasının zaman kaybına neden olduğu şeklindedir. Örneğin, bir uzman hekim şu şekilde yanıt vermiştir; "Tez istatistiklerimi tez hocam yaptı, zaman kaybına neden oldu". Bir diğer uzman hekim ise "Tez çalışmamsa istatistik işlemleri istatistik uzmanı tarafindan yapıldı ve gecikmeden dolayı tez sürem uzadı" şeklinde yanıt vermiştir. Bir uzman ise "Başkasından yardım almak gecikmeye sebep oldu, ben bilseydim daha güzel istatistikler yapardım" şeklinde yanıtlamıştır. Tez çalışmaları için bir başka kişiden yardım alan uzmanlardan üçü ise sorun yaşamadığını belirtmiştir.

Araştırmanın üçüncü alt amacı doğrultusunda katılımcılara "Bilimsel çalışmalarınız için lisans eğitiminizde aldığınız istatistik içerikli derslerinizin (biyoistatistik vb.) yeterli olduğunu düşünüyor musunuz? Görüşleriniz nelerdir?" sorusu yöneltilmiştir. Katılımcı yanıtlarından elde edilen bulgular Tablo 6'da yer almaktadır. Tablo 6 incelendiğinde uzman hekimler lisans eğitimleri kapsamında aldıkları istatistik içerikli derslerin bilimsel çalışmaları için görüşlerine göre 102 uzman hekim yetersiz olarak görürken, 15 uzman hekim yeterli olduğunu düşünmektedir. Uzman hekimlerden 48'i ise lisans eğitiminde alınan istatistik içerikli derslerin yeterli görülme durumlarına ilişkin açıklamalarda bulunmuştur. Lisans eğitiminde alınan istatistik içerikli eğitimlerin alındığ 1 zamana bağlı olarak, yeterli olduğu görüşüne sahip yedi kişi, yetersiz olduğu görüşüne sahip iki kişi alınan eğitimin uzun süre önce alınması nedeniyle unutulduğunu belirtmektedir. Örneğin bir uzman hekim "lisans eğitiminde var ancak biz uzun zaman kullanmadığımız için unutuyoruz" yanıtını vermiştir. Bir diğer uzman hekim ise "iş yoğunluğu fazla ve eğitim lisansın ilk zamanlarında oluyor o yüzden unutuldu" şeklinde yanttlamıştır. Lisans eğitiminde alınan istatistik içerikli eğitimlerin alındığ 1 zamana bağlı olarak belirtilen bir diğer görüş ise 11 uzman tarafindan benimsenen, istatistik derslerinin lisans eğitimin son yıllarında alınması gerektiği görüşüdür. Örneğin, bir uzman hekim "Özellikle ilk senelerde verilmesi yanlış son senelerde verilmeli" yanıtını verirken bir diğer uzman hekim ise "Lisans eğitiminin son senesinde bir eğitim olabilir" yanıtını vermiştir. Zamana bağl1 olarak belirtilen bir diğer görüş ise istatistik derslerinin uzmanlık eğitiminde alınması gerektiği görüşüdür. Örneğin bu görüşe sahip beş uzmandan biri "Özellikle uzmanlık eğitiminde mutlak olmalı", bir başka uzman hekim ise "Asistanlıkta eğitimi mutlaka olmalı" yanıtını vermiştir.

Tıp eğitiminin lisans düzeyinde alınan istatistik derslerinin içeriğine bağlı olarak uygulamalı olmas1 gerektiği görüşünü ise 10 uzman hekimin belirttiği görülmektedir. Örneğin bir uzman hekim "Lisans eğitiminde teorik dersler yeterli ancak uygulama eksik" olduğu görüşündedir. Bir diğer uzman hekim ise "Teorik olarak yeterli pratik olarak yetersiz" yanıtını vermiştir. Uzman hekimler lisans eğitimlerinde aldıkları istatistik derslerinin içeriğine bağlı olarak da belirtilen farklı diğer görüşler ise şu şekildedir; "yurt dışı stajımda daha fazla öğrendim”, "daha profesyonel destek 


\begin{tabular}{lll}
\hline & $\mathrm{f}$ & $\%$ \\
\hline Evet & 101 & 86,32 \\
Hayır & 15 & 12,82 \\
Kararsızım & 1 & 0,85 \\
Toplam & 117 & 100,00 \\
\hline
\end{tabular}

daha güzel olur", "eğitimlerin anlaşılır olması ve güncellenmesi gerektiğini düşünüyorum”. Araştırmanın dördüncü alt amacı doğrultusunda katılımcılara "Tıpta uzmanlık eğitimde İstatistik dersi yer almalı mıdır? Görüşleriniz nelerdir?" sorusuna verdikleri yanıtlar değerlendirilmiştir. Buna göre elde edilen bulgular Tablo 7'de yer almaktadir.

Tıpta uzmanlık eğitiminde istatistik dersinin yer almasına ilişkin olarak 117 uzman hekimden 101'i böyle bir dersin olması gerektiğini, 15'i gerek olmadığını, biri ise kararsız olduğunu belirtmiştir. Bununla birlikte gerekli olduğunu düşünenler uzmanlık eğitiminin başından sonuna hem teorik hem de özellikle uygulamalı eğitimlerin olması gerektiğini, ayrıca sadece son yıllarda olmasının daha iyi olacağını, seçmeli olabileceği, diğer bölümlere yapılanlara benzer olarak rotasyon şeklinde en az bir aylık süreyle istatistik eğitimlerinin alınması gerektiği görüşündedirler. Uzmanlık eğitiminde istatistik dersinin yer almaması gerektiğini belirten uzman hekimler ise genellikle bir neden belirtmemekle birlikte, bu türlü derslerin iş yoğunluğundan dolayı fazla verimli olamayacağını, isteyen kișilerin kendi özel çabalarıyla bu türlü yeterliliklere sahip olmaları gerektiğini, asıl ilgi alanlarının hasta tedavisi olması gibi nedenlerden bahsetmektedirler.

Araştırmanın beşinci ve son alt amacı doğrultusunda "Genel olarak tıpta uzmanlık eğitiminde istatistiğin yeri ile ilgili ne düşünüyorsunuz? Görüşleriniz nelerdir?"' sorusuna verilen yanitlardan elde edilen bulgulara Tablo 8'de yer verilmiştir.

Tablo 8 incelendiğinde tıpta uzmanlık eğitiminde istatistiki yeterlilikler bakımından yetersiz olduğu görüşünde olan 99, yeterli olduğu görüşünde olan iki uzman hekim bulunmaktadır. Bununla birlikte her uzman istatistik öğrenmek zorunda değil, istatistik eğitimine gerek yok, danışman desteği ile sağlanabilir, istatistiki terimler Türkçeleştirilmeli gibi görüşler de yer almaktadır. Yetersiz olduğunu düşünen hekimlere göre uzmanlık eğitiminde akademik başarıdan daha çok sağlık hizmetlerinin yürütülmesine önem verildiği, uzmanlık eğitiminin genel olarak standart bir süreç olarak yürütülememesi nedeniyle istatistik eğitiminde bir standart olmadığı, uzmanlık eğitimi sürecinde iş yükünün fazla olduğu, kişi kendi

Tablo 8. Tıpta Uzmanlık Eğitimi ve İstatistiki Yeterlilikler ile İlgili Yanıtların Dağılımı

\begin{tabular}{lll}
\hline & $\mathrm{f}$ & $\%$ \\
\hline Yetersiz & 99 & 84,62 \\
Yeterli & 2 & 1,71 \\
Her uzman istatistik öğrenmek zorunda değil & 2 & 1,71 \\
İstatistik eğitimine gerek yok & 1 & 0,85 \\
Danışman desteği ile sağlanabilir & 1 & 0,85 \\
İstatistiki terimler Türkçeleştirilmeli & 1 & 0,85 \\
Boş & 11 & 9,40 \\
Toplam & 117 & 100 \\
\hline
\end{tabular}


imkanları doğrultusunda bu türlü yeterliliklere sahip olduğunu, akademisyenlikten soğutan sebeplerden biri olduğu şeklinde görüşlerin bulunduğu görülmektedir.

Katılımcilar; istatistik alanında uzman bireylerden gerekli eğitimlerin alınması, uzmanlık eğitiminde istatistik eğitiminin olması gerektiği, sağlık kurumlarında araştırma danışmanlık ve eğitim merkezleri açılıp hem danışmanlık hem de eğitim yeri olarak kullanılabileceği, uygulama eğitimlerinin olması, kısa süreli kurs veya sertifika programları düzenlenmesi, tıp eğitiminin her yılında ders olması gerekliliği, istatistik derslerinin tıp eğitiminin ileri yıllarında olması gerektiği, akademik hayata da hazırlanılması gerektiği, akademisyenlik düşünenler için ek eğitim verilebileceği, seçmeli ders olarak bulunabileceği, rotasyon eğitimi olması gibi önerilerde bulunmuşlardır.

\section{TARTIŞMA VE SONUÇ}

Uzman hekimlerin istatistiki yeterliliklerine ilişkin görüşlerinin incelenmesinin amaçlandığ 1 bu araştırma ile elde edilen bulgular doğrultusunda görüşme sorularına verilen yanıtlara göre ulaşılan sonuçlara bu başlık altında yer verilmiştir.

Uzman hekimler hem tez çalışmaları hem de diğer bilimsel çalışmalar bakımından istatistiki yeterlilikleri noktasında kendilerini yetersiz olarak nitelendirmektedir. Bu sonucun, 2002 yılından itibaren tıp fakültelerinde yürütülen eğitimde kazandırılması hedeflenen beceri ve tutumların yer aldığı "Ulusal Çekirdek Eğitim Programı"nda "Bilimsel bilgiyi üreten bireyler yetiştirmek" temeline dayanan herhangi bir hedefe rastlanmaması ile doğrudan ilişkili bir sonuç olduğu görülmektedir (6).

İstatistiki yeterlilikler anlamında kendini yetersiz olarak belirten hekimler, bilimsel çalışmaları için gerekli istatistiki işlemler için birçok şekilde ve yoldan yardım aldıklarını belirtmişlerdir. Uzmanlar en çok istatistik uzmanından yardım alırken bunu Biyoistatistik bölümü öğretim üyeleri ve kendi bölüm öğretim üyeleri izlemektedir. Ancak aldıkları yardımlar sonucunda önemli olumsuzluklarla karşılaşmaktadırlar. Bu sorunlar yardım aldıkları kişiler, elde edilen bulguları değerlendirme, tez istatistiklerinin yardım alınarak yapılmasının zaman kaybina neden olması ile ilgili sorunlar yaşadıklarını belirtmektedirler. Bununla birlikte uzman hekimler eğer bu yardımı ücret karşılığ1 aldılar ise talep edilen ücretlerin çok yüksek olduğu görüşündedirler. Elde edilen bu sonuçlar ile uzman hekimlerin araştırma yöntemleri ve istatistik konularında destek bulmakta güçlük çektiklerini belirttikleri bir diğer araştırma sonucu ile benzerlik göstermektedir (14).

Tıp eğitiminde istatistik içerikli alınan dersler lisans eğitimi sürecinde yer almaktadırlar. Araştırmaya katılan uzman hekimler lisans eğitiminde aldıkları istatistik içerikli derslerin (biyoistatistik vb.) ise bilimsel çalışmalar noktasında yetersiz kaldığını belirtmişlerdir. $\mathrm{Bu}$ sonuç istatistik içerikli dersler bakımından bir standart olmaması ile ilişkilendirebilir. Türkiye'de bulunan tıp fakültelerinin eğitim programlarının incelendiği bir araştırmada tıp eğitim bakımından bir standart olmadığ1 görülmektedir (6). Tıp fakülteleri eğitim programlarının incelendiği diğer iki çalışmada ise istatistik veya biyoistatistik içerikli derslerin yer aldığ 1 ancak bu anlamda bir standart olmadığı sonucuna ulaşılmıştır $(9,10)$. Bir diğer çalışma sonucuna göre tıp fakültesi eğitim programları istatistiksel beceriler anlamında oldukça yetersiz olarak belirlenmiştir (11). Uzman hekimlerin istatistik içerikli aldıkları dersleri yetersiz olarak belirtmesi sonucu, uzman hekimlerin araştırma yöntemleri üzerine yeterli bir eğitim almadıklarını belirttikleri çalışmayı da desteklemektedir (14).

Mezuniyet öncesi tıp eğitiminde istatistik derslerinin istatistiki yeterlilikler anlaminda yetersiz görülme nedenleri arasında alındığı zamana bağlı olarak uzun süre önce alınması, 
lisans eğitiminin son yıllarında alınması ve uzmanlık eğitiminde alınması gerektiği şeklinde sıralanmaktadır. İstatistik derslerinin içeriğine bağlı olarak belirtilen görüşler ise derslerin daha çok uygulamalı olarak yürütülmesi yönündedir. $\mathrm{Bu}$ türlü derslerin sadece lisans eğitiminde alınan derslerle sınırlı olması tıp eğitiminde önemli bir eksiklik olarak görülmektedir. Daha önce de belirtildiği gibi istatistik eğitiminin istatistik okuryazarlığı çerçevesinde yürütülmesi önerilmektedir (19; 20). Uzman hekimlerin görüşleri incelendiğinde ise mezuniyet öncesi tıp eğitiminde yer alan istatistik eğitiminin istatistik okuryazarlığı anlamında eksik görüldüğü söylenebilir

Uzmanlık eğitimi sürecinde bireysel çabalar dışında istatistik eğitimine ilişkin program dahilinde herhangi bir eğitim yer almamaktadır. Uzman hekimler çoğunlukla uzmanlık eğitiminde istatistik dersinin yer alması gerektiği görüşündedirler. $\mathrm{Bu}$ derslerin uzmanlık eğitiminin başından sonuna hem teorik hem de özellikle uygulamalı şekilde, sadece son yıllarında, diğer bölümlere yapılanlara benzer olarak rotasyon şeklinde en az bir aylık süreyle istatistik eğitimlerinin alınması gerektiği şeklinde önerilerde bulunmuşlardır. $\mathrm{Bu}$ noktada bu durumun tıp eğitimi açısından önemli bir eksiklik olduğu dikkat çekmektedir. Bununla birlikte uzmanlık eğitiminde istatistik dersinin yer almaması gerektiğini belirten az sayıda katılımcıda bulunmaktadır. $\mathrm{Bu}$ görüşte olan uzman hekimler genellikle bu duruma ilişkin bir neden belirtmemekle birlikte, bu türlü derslerin iş yoğunluğundan dolayı fazla verimli olamayacağını, isteyen kişilerin kendi özel çabalarıyla bu türlü yeterliliklere sahip olmaları gerektiğini, asıl ilgi alanlarının hasta tedavisi olması gibi nedenleri öne sürmüştür. Ancak daha önce de belirtildiği gibi bu görüşte olan oldukça az sayıda uzman hekim bulunmaktadır. Jinekologların istatistik okuryazarlığı eğitimlerini en çoktan en aza doğru dergi kulüpleri, informal eğitimler, derslerin bir bölümünde ve herhangi bir eğitim almadıkları şeklinde belirtmektedirler (32). Patologlar ise istatistik okuryazarlığına ilişkin yapılan bir çalışmada ise istatistiksel teknikler noktasında genellikle hiçbir bilgilerinin olmadığını veya temel bilgi seviyesinde olduklarını belirtmişlerdir (31). Buna göre hekimler için istatistiksel yeterlilikler yalnızca bilimsel çalışmalar yürütebilmek adına değil, tıbbi kararlar alabilmek, bilimsel dergilerde yer alan çalışmaları anlayabilmek adına da gerekli görülmektedir.

Araştırmada son olarak uzman hekimlerden tıpta uzmanlık eğitiminde istatistiğin yeri ile ilgili görüşlerini belirtmeleri istenmiştir. Genel olarak yetersiz olduğunu düşünen hekimlere göre uzmanlık eğitiminde akademik başarıdan daha çok sağlık hizmetlerinin yürütülmesine önem verildiği, uzmanlık eğitiminin genel olarak standart bir süreç olarak yürütülememesi nedeniyle istatistik eğitiminde de bir standart olmadığı, uzmanlık eğitimi sürecinde eğitim alan hekimlerin iş yükünün fazla olduğu, ancak bireysel çabalar doğrultusunda istatistiki yeterliliklere sahip olabildikleri, istatistiki anlamda yaşanılan problemlerin akademisyenlikten soğutan sebeplerden biri olduğu görüşündedirler.

Uzman hekimlerin tıp eğitiminde istatistiğin yerine ilişkin görüşleri doğrultusunda getirdikleri öneriler ise şu şekildedir; uzmanlık eğitiminde istatistik eğitiminde yer alması bunun kurs veya sertifika programlarıyla desteklenmesi, sağlık kurumlarında çalışanlara yönelik hizmet verebilecek araştırma danışmanlık ve eğitim merkezlerini bulunması gerekliliği önemli öneriler arasında yer almaktadır. İstatistik kursu alma durumları ile araştırma yayınlama arasındaki pozitif ilişki bu türlü eğitimlerin önemini ortaya koymaktadır (31).

Tıpta uzmanlık öğrencileri üzerinde yapılan bir çalışmada da bu çalışmanın sonucuna benzer şekilde öğrenciler sağlık hizmetlerinin yoğun olduğu, aldıkları eğitimden tatmin olmadıkları, 
başarı ve yeterlilikler anlamında eksik olduğunu düşünmektedirler (15). Bir diğer çalışma ise uzman hekimler araştırma yöntemlerine ilişkin yeterli bir eğitim almadıklarını, bu anlamda kısmen destek bulduklarını ve araştırma yapmakta problem yaşadıklarını, eğitim sürecine mutlaka araştırma yöntemlerine ilişkin bir öğretim programının dahil edilmesi gerektiğini belirtmişlerdir (14).

Araştırmadan elde edilen bulgular doğrultusunda uygulayıcılara yönelik öneriler şu şekildedir. Uzmanlık eğitiminde hasta hizmetleri kadar bilimsel çalışmalara da yeterince önem verilmeli bu duruma kurumdan bağımsız bir standart getirilmelidir. Tıp eğitiminde istatistiğin yerine ilişkin olarak gerekli çalışmaların yapılıp hem lisans düzeyinde hem de uzmanlık eğitimi düzeyinde istatistik eğitiminin yer aldığı değişiklikler program dahilinde yapılmalıdır. Uzman hekimlerin bilimsel çalışma yapabilmeleri için gerekli ortamlar oluşturulmalıdır. Hekimler, bilimsel çalışmalar noktasında maddi ve manevi olarak yeterince destek görmedikleri görüşündedir. $\mathrm{Bu}$ nedenle hekimlere gerekli desteğin verilmesi bilimsel çalışmaların nitelik ve nicelikleri anlamında oldukça etkili olacaktır. Ancak bu durum kurumların inisiyatifine bırakılmamalıdır. Bilimsel çalışmaların istatistik işlemlerinin araştırmacı dışında bir yolla gerçekleştirilmesinin araştırmanın güvenilirliğini olumsuz etkileyebileceği durumu ile ilgili gerekli bilgilendirmeler yapılmalıdır. Hekimlerin bilimsel çalışmalarını yürütürken istatistiki anlamda yardım almalarının ilgili çalışmaların güvenirliğini doğrudan olumsuz bir şekilde etkilediği söylenemez. Eğer hekim (araştırmacı) ve yardım alınan birey arasındaki iş birliği verimli bir şekilde yürütülebilirse bu durum araştırmanın niteliğini arttıracaktır. Araştırma için alınan istatistiki anlamda bir yardımın niteliği oldukça önemli görünmektedir. Araştırmacılara yönelik öneriler ise şu şekildedir; uzmanlık eğitiminde istatistik eğitiminin nasıl, ne şekilde ve ne kadar süre ile yer alması gerektiği araştırılmalıdır. Tıpta uzmanlık eğitiminde başarılı ülkeler belirlenerek istatistik eğitiminin yeri incelenmelidir. Diğer ülkelerin bu konudaki durumları incelenerek karşılaştırmalı çalışmalar yapılabilir. Türkiye'de uzman hekimlerin istatistik okuryazarlığının incelendiği bir çalışmaya rastlanmamıştır. Buna göre Türkiye'de bu türlü bir araştırma yürütülebilir.

\section{KAYNAKLAR}

1. Kemahlı S. Türkiye'de Tıp Eğitimi Çalışmaları ve “Tıp Eğitimi Dünyası” Dergisi. Tıp Eğitimi Dünyası Dergisi. 45. Ek Özel Sayı; (2016).

2. Turan, Özdemir S. Tıp Eğitimi ve Standartlar. Uludağ Üniversitesi Tıp Fakültesi Dergisi. 2005; 31(2): 133-137

3. Lilley, P., M. Harden, R., M. Standards and medical education. Medical Teacher. 2003; 25:349-51

4. Leinster, S. Standards in medical education in the European Union. Medical Teacher. 2003; 25:507-9

5. UÇEP. Ulusal Çekirdek Eğitim Programı. Ankara, 2001.

6. Turan S, Sincan M, Elçin M, Odabaşı O Sayek

İ. Tıp Fakültelerinde Klinik Öncesi Dönemde Araştırma Eğitim. Tıp Eğitimi Dünyası. 2007; Say1 26 
7. Gültekin B, Söylemez A, Dereboy IF. Çiçek C. Ege ve Adnan Menderes Tıp Fakültelerinde Uzmanlık Eğitimi Tıpta Uzmanlık Öğrencisi Bakış Açısı İle. Adnan Menderes Üniversitesi Tıp Fakültesi Dergisi. 2006; 7(2) : $17-21$

8. Yarış F, Topbaş M, Çan G. Özoran Y. Karadeniz Teknik Üniversitesi Tip Fakültesi Öğrencilerinin Tıp Eğitimi Hakkında Görüşleri. Ondokuz Mayıs Üniversitesi T1p Dergisi. 2001; 18(4): 233-241

9. Looney SW,Grady CS Steiner RP An update on biostatistics requirements in U.S. medical schools, Academic Medicine. 1998; 73, pp. 92-94.

10. Britta L Anderson, [J Schulkin. Numerical Reasoning in Judgments and Decision Making about Health. Washington, DC: Cambridge University Press; 2014.

11. Rao G, Kanter S L. Physician Numeracy as the Basis for an Evidence-Based Medicine Curriculum. Academic Medicine. November 2010; Volume 85- Issue 11- p 1794-1799doi: 10.1097/ACM.0b013e3181e7218c

12. Karasar N. Bilimsel Araştırma Yöntemi. Ankara: Nobel Yayın Dağıtım; 2016.

13. Tıpta ve Diş Hekimliğinde Uzmanlık Eğitimi Yönetmeliği. Resmi Gazete (Sayı:28983). Erişim adresi: http://www.mevzuat.gov.tr/Metin. Aspx?MevzuatKod=7.5.19629\&MevzuatIliski $=0 \&$ sourceXmlSearch=t (26 Nisan, 2014)

14. Saydam M B, Özgülnar N ve Darendeliler F. Tıpta Uzmanlık Tezi: Tartışılan Sürece Bir Araştırma Kapsamında Bakış. Yükseköğretim ve Bilim Dergisi. (2014); 4(3):176-181

15. Gölboyu B E, Dölgeroğlu O, Ekinci M, Kızıloğlu I, Sarı E, Karaca Baysal P. Doğu Anadolu Bölgesinde İkinci Basamak Sağlık
Kuruluşlarında Görev Yapan Uzman Hekimlerin Sürekli Tıp Eğitimi Faaliyetleri. Tepecik Eğit. ve Araştırma Hastanesi Dergisi. 2015; 25(3):179

16. Gökçe Kutsal Y, Korkmaz N. Ulusal Süreli Yayınlarımıza Eleştirel Bakış. Yılmaz O TÜBİTAK Ankara: Sağlık Bilimlerinde Süreli Yayıncılık; 339-45, 2005.

17. Yavuz D G, Cavdar S, Erenus M. Bir Tıp Fakültesinde Eğitimin ve Bilimsel Araştırmaların 27 Yıllık İzlemi: Marmara Üniversitesi Tıp Fakültesi. Marmara Medical Journal. 2011; 24 (1):1-9

18. Avcı K, Pala K. Uludağ Üniversitesi Tıp Fakültesinde Çalışan Araştırma Görevlisi ve Uzman Doktorların Yaşam Kalitesinin Değerlendirilmesi. Uludağ Üniversitesi Tıp Fakültesi Dergisi. 2004; 30 (2) 81-85

19. Schau C, Emmioğlu E. Do Introductory Statistics Courses in the United States Improve Students' Attitudes? Statistics Education Research Journal. 2012; 11(2), 86-94. http:// www.stat.auckland.ac.nz/serj

20. Ben-Zvi D, Garfield J. Statistical literacy, reasoning and thinking: Goals, definitions and challenges. D. Ben-Zvi J. Garfield (Ed.), The challenge of developing statistical literacy, reasoning and thinking içinde (s. 3-16). The Netherlands: Kluwer Academic Publishers; 2004.

21. Callingham R, Watson J M. Measuring statistical literacy. Journal of Applied Measurement. 2005; 6 (1),29, 19-47

22. Gal I. The Challenge of Developing Statistical Literacy, Reasoning and Thinking. İçinde Ben-Zvi D. \& Garfield J. (Ed.), Statistical Literacy - Meanings, Components, Responsibilities (pp.47-78). America: Kluwer Academic Publishers; 2004. 
23. Garfield J, Ben-Zvi D. How Students Learn Statistics Revisited: A Current Review of Research on Teaching and Learning Statistics. International Statistical Review. 2007; 75, 3, 372-396. https://doi.org/10.1111/j.17515823.2007.00029.x

24. Lehohla P. Promoting statistical literacy: A South African perspective. İçinde B. Phillips, (Ed.), Proceedings of the Sixth International Conferences on Teaching Statistics. Voorburg, the Netherlands: International Statistical Institute; 2002.

25. del Mas R C. Statistical literacy, reasoning, and learning: A commentary. Journal of Statistics Education. 2002; 10(3). http://www.amstat.org/ publications/jse/v10n3/delmas_discussion.html adresinden elde edildi.

26. Rumsey D J. Discussion: Statistical literacy: Implications for teaching, research and practice. International Statistical Review. 2002; 70, 3236.

27. Wallman K K. Enhancing statistical literacy: Enriching our society. Journal of the American Statistical Association. 1993; 88(421),1-8.

28. Watson J M. Assessing statistical literacy using the media. İçinde I. Gal \& J. B. Garfield (Eds.), The assessment challenge in statistics education (pp. 107-121). Amsterdam, The Netherlands: IOS Press\&The International Statistical Institute; 1997.

29. Watson J M, Callingham R. Statistical literacy: A complex hierarchical construct. Statistics Education Research Journal. 2003; 2(2),3-46.

30. Lancet. Mathematics and Medicine. 1937; 229 (5914), 31.

31. Schmidt R L, Chute D J, Colbert-Getz J M, Firpo-Betancourt A, James D S, Karp J K ve diğerleri. Statistical Literacy Among Academic Pathologists: A Survey Study to Gauge Knowledge of Frequently Used Statistical Tests Among Trainees and Faculty. Arch Pathol Lab Med. 2017; 141(2):279-287.

32. Anderson B L, Williams S, Schulkin J. Statistical Literacy of Obstetrics-Gynecology Residents. Journal of Graduate Medical Education: June 2013; Vol. 5, No. 2, pp. 272275.

33. Yıldırım A ve Şimşek H. Sosyal bilimlerde nitel araştırma yöntemleri. Ankara: Seçkin Yayınc1lık; 2005.

34. Creswell J W, Hanson WE, Plano V L C, Morales A. Qualitative Research Designs: Selection and Implementation. The Counseling Psycholog1st. 2007; Vol. 35 No. 2, March 2007 236-264 DOI: 10.1177/0011000006287390

35. Patton M Q. How to use qualitative methods in evaluation. Los Angeles: Sage Publications; 1987.

36. Balcı A. Sosyal Bilimlerde Araştırma Yöntem, Teknik ve İlkeler. Ankara: Bilgisayar Yayınc1lık; 1997.

37. Simon J. Burstein P. Basic Research Methods İn Social Sciences. New York: Random House; 1985.

38. Tavşancıl E, Aslan E. Sözel, Yazılı ve Diğer Materyaller için İçerik Analizi ve Uygulama Örnekleri. İstanbul: Epsilon Yayınevi; 2001.

39. Miles M B, Huberman A M. Qualitative Data Analysis: An Expanded Source Book. (2nd ed). Thousand Oaks, CA: Sage Publications; 1994. 